Keywords: Cesium,

Tetraphenylborate

Retention: Permanent

\title{
Analyses of HTF-48-12-20/24 (February, 2012) and Archived HTF-E-05-021 Tank 48H Slurry Samples
}

\section{A. Nash \\ T. B. Peters}

August 2, 2012

Savannah River National Laboratory

Savannah River Nuclear Solutions

Aiken, SC 29808

Prepared for the U.S. Department of Energy under 
SRNL-STI-2012-00420

Revision 0

\section{DISCLAIMER}

This work was prepared under an agreement with and funded by the U.S. Government. Neither the U.S. Government or its employees, nor any of its contractors, subcontractors or their employees, makes any express or implied:

1. warranty or assumes any legal liability for the accuracy, completeness, or for the use or results of such use of any information, product, or process disclosed; or

2. representation that such use or results of such use would not infringe privately owned rights; or

3. endorsement or recommendation of any specifically identified commercial product, process, or service.

Any views and opinions of authors expressed in this work do not necessarily state or reflect those of the United States Government, or its contractors, or subcontractors.

\section{Printed in the United States of America}

Prepared for

U.S. Department of Energy 


\section{REVIEWS AND APPROVALS}

AUTHORS:

C. A. Nash, Author, SRNL/ACP

Date

T. B. Peters, Author, SRNL/SASP

Date

TECHNICAL REVIEW:

C. J. Martino, Technical Reviewer, SRNL/ACP

Date

APPROVAL:

S. D. Fink, SRNL/SSP, Manager

Date 


\section{TABLE OF CONTENTS}

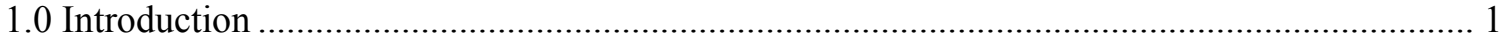

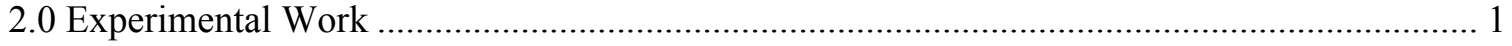

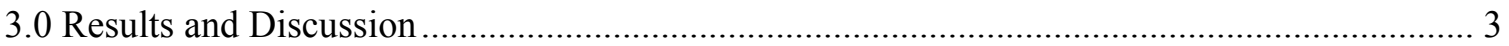

3.1 Slurry Sample Results for the HTF-48-12-20/24 Composite ….......................................... 3

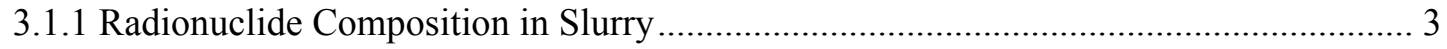

3.1.2 Inductively Coupled Plasma Emission Spectroscopy (ICP-ES) for Digested Slurry ...... 4

3.1.3 Inductively Coupled Plasma Mass Spectroscopy (ICP-MS) ........................................... 6

3.1.4 Volatile and Semivolatile Organic Analyses for Slurry .................................................. 6

3.1.5 High Performance Liquid Chromatography (HPLC) ….................................................. 7

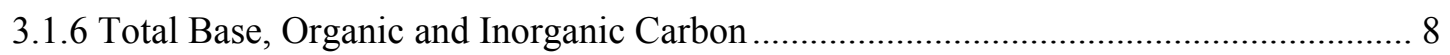

3.2 HTF-48-12-20/24 Composite Filtrate Sample Results ....................................................... 8

3.2.1 IC Anions, Total Base, and Organic and Inorganic Carbon.......................................... 9

3.2.2 Filtrate Mercury by Cold Vapor Atomic Absorption .................................................. 10

3.2.3 Inductively Coupled Plasma Mass Spectroscopy of Filtrate......................................... 10

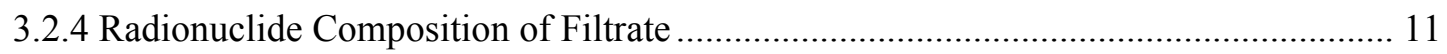

3.2.5 Inductively Coupled Plasma Emission Spectroscopy of Filtrate .................................. 12

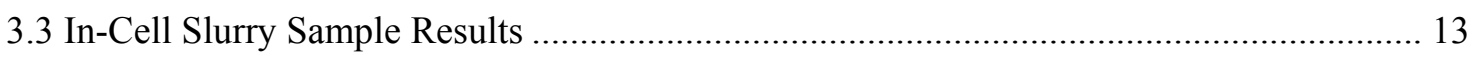

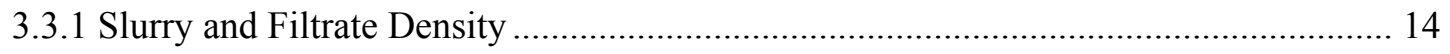

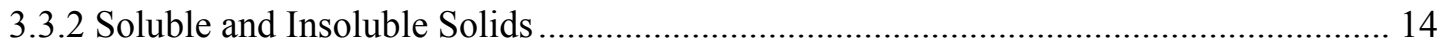

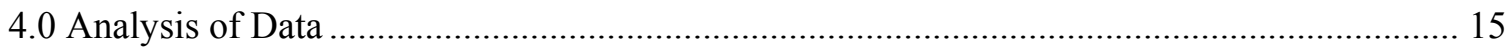

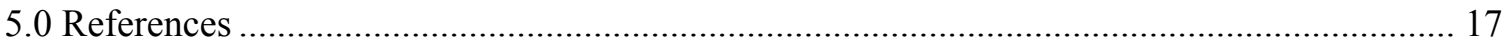




\section{LIST OF TABLES}

Table 1. Summary of Significant Tank 48H Composite Sample Results (HTF-48-12-20/24) .... vii

Table 2. Analysis of Tank 48H Slurry Samples .......................................................................... 2

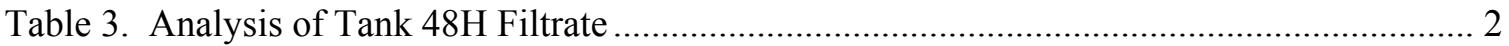

Table 4. Slurry Radionuclide Composition Data, dpm/mL ........................................................ 3

Table 5. Americium, Curium, and Californium in HTF-48-12-20/24 Slurry …............................ 4

Table 6. Comparison of ICP-ES Data for Slurry Samples ……................................................ 5

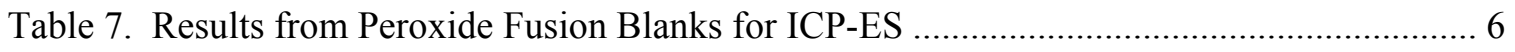

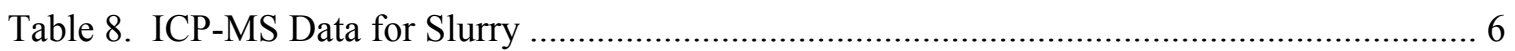

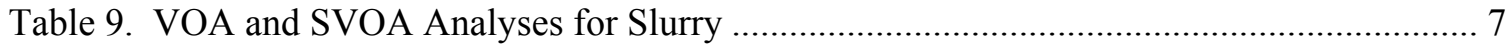

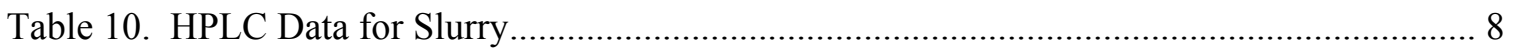

Table 11. Total, Free and Other Base Content of Slurry …......................................................... 8

Table 12. Anion, Base and Carbon Content of Filtrate ……....................................................... 9

Table 13. Comparison of IC Anions Results with Those of F/H Lab ........................................ 10

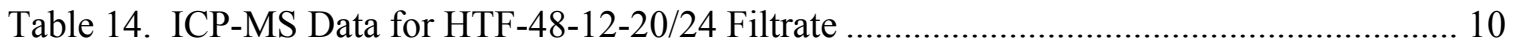

Table 15. Comparison of Current Filtrate ICP-MS Data with the 2005 Sample.......................... 11

Table 16. Comparison of Current Filtrate ICP-MS Data with the 2003/2004 Samples ............... 11

Table 17. Comparison of Filtrate Radiochemistry Data ............................................................ 12

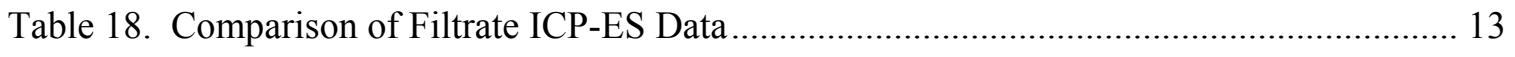

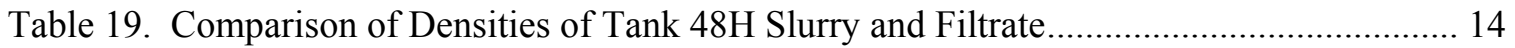

Table 20. Comparison of Solids Data with those of Previous Samples ..................................... 15

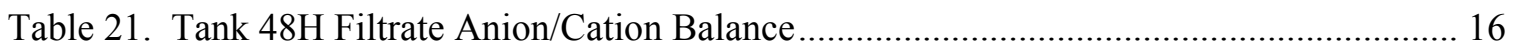




\section{Acknowledgements}

This task required the support of a large team of people. We thank the following individuals but note that many others assisted in completing this task.

We thank the dedicated Shielded Cells Technicians, especially Dee Wheeler and Monica Jenkins for receiving the Tank $48 \mathrm{H}$ samples, completing the analyses in the cells as requested and preparing/exiting samples for transfer to AD. We thank Paul Burket for assistance with planning for sample handling and in-cell mixing of the samples.

We thank the following personnel in the Analytical Development Section. We list the researchers involved but omit the many technicians supporting them to complete this task on schedule. Thanks to Leigh Brown, Amy Ekechukwu, Steve Crump, Boyd Wiedenman, Tom White, David DiPrete, Ceci DiPrete, Chuck Coleman, and Damon Click.

We appreciate the support of the Tank $48 \mathrm{H}$ team for their technical support in helping us accomplish this task. 


\section{EXECUTIVE SUMMARY}

Personnel characterized a Savannah River National Laboratory (SRNL) archived sample of Tank 48H slurry (HTF-E-05-021) in addition to the composite of samples HTF-48-12-20 and HTF-4812-24, which were both retrieved in February 2012. The combined February 2012 sample is referred to as HTF-48-12-20/24 in this report. The results from these analyses are compared with Tank $48 \mathrm{H}$ samples analyzed in $2003^{1}, 2004^{2}$, and $2005 .^{3}$ This work supports the effort to demonstrate copper-catalyzed peroxide oxidation (CCPO) of organic content in this material. The principal findings with respect to the chemical and physical characteristics of the most recent sample follow.

- The measured potassium tetraphenylborate (KTPB) solid concentration is $1.76 \mathrm{wt} \%$.

- Titanium was in line with 2004 and 2005 slurry measurements at $897 \mathrm{mg} / \mathrm{L}$. It represents $0.1535 \pm 0.0012 \mathrm{wt} \%$ monosodium titanate (MST).

- The measured insoluble solids content was $1.467 \mathrm{wt} \%$.

- The free hydroxide concentration in the Tank $48 \mathrm{H}$ filtrate sample $(1.02 \pm 0.02 \mathrm{M})$ is close to the Tank $48 \mathrm{H}$ limit $(1.0 \mathrm{M})$.

- Carbonate reported by total inorganic carbon (TIC, $1.39 \pm 0.03 \mathrm{M}$ ) is more than double the concentrations measured in past (2003-2005) samples.

- The soluble potassium content (measured at $286 \pm 23 \mathrm{mg} / \mathrm{L}$ ) in the filtrate is in line with all past measurements.

- The measured ${ }^{137} \mathrm{Cs}$ concentration is $7.81 \mathrm{E}+08 \pm 3.9 \mathrm{E}+07 \mathrm{dpm} / \mathrm{mL}$ of slurry $(1.33 \pm 5 \%$ $\mathrm{Ci} /$ gallon or $3.18 \mathrm{E}+05 \pm 5 \%$ curies of ${ }^{137} \mathrm{Cs}$ in the tank) in the slurry which is in agreement with the 2005 report of $3.14 \mathrm{E}+05 \pm 1.5 \%$ curies of ${ }^{137} \mathrm{Cs}$ in the tank ${ }^{3}$. The filtrate ${ }^{137} \mathrm{Cs}$ concentration is $2.57 \mathrm{E}+07 \pm 2.6 \mathrm{E}+05 \mathrm{dpm} / \mathrm{mL}$. This result is consistent with previous results. Significant analytical data are summarized in Table 1.

Table 1. Summary of Significant Tank 48H Composite Sample Results (HTF-48-12-20/24)

\begin{tabular}{|c|c|c|c|}
\hline Analyte & Slurry & Supernate & Source \\
\hline Density, $\mathrm{g} / \mathrm{mL}$ & $1.219 \pm 0.011$ & $1.198 \pm 0.01$ & Density \\
\hline Total Solids, wt \% & $23.23 \pm 0.06$ & $22.08 \pm 0.4$ & Solids \\
\hline Total Insolubles, wt \% & $1.467 \pm 0.873$ & NA & Calculation \\
\hline KTPB, wt \% & 1.76 & NA & HPLC \\
\hline MST solids, wt \% & $0.1535 \pm 0.0012$ & $<0.5 \mathrm{mg} / \mathrm{L}$ & ICP-ES \\
\hline \multicolumn{4}{|l|}{ Metals } \\
\hline Sodium, $\mathrm{M}$ & NM & $3.73 \pm 0.33$ & ICP-ES \\
\hline Potassium, M & $0.0826 \pm 0.0056$ & $0.0073 \pm 0.0006$ & ICP-ES \\
\hline \multicolumn{4}{|l|}{ Anions } \\
\hline Free Hydroxide, $\mathrm{M}$ & $0.652 \pm 0.229^{*}$ & 1.02 & Titration \\
\hline Nitrite, $\mathrm{M}$ & NM & $0.534 \pm 0.0158$ & Anion \\
\hline Nitrate, $\mathrm{M}$ & $\mathrm{NM}$ & $0.177 \pm 0.0232$ & Anion \\
\hline \multicolumn{4}{|l|}{ RadChem } \\
\hline${ }^{137} \mathrm{Cs}, \mathrm{dpm} / \mathrm{mL}$ & $\begin{array}{c}7.81 \mathrm{E}+08 \pm \\
3.9 \mathrm{E}+07\end{array}$ & $\begin{array}{c}2.57 \mathrm{E}+07 \pm \\
2.6 \mathrm{E}+05\end{array}$ & Gamma scan \\
\hline
\end{tabular}




\section{LIST OF ABBREVIATIONS}

1PB - phenylborinic acid

2PB - diphenylboronic acid

3PB - triphenylboron

AD - Analytical Development

CCPO - Copper-catalyzed peroxide oxidation

DI - Deionized (water)

DS - Dissolved Solids

F/H ALS - F/H Area Laboratory Services

HPLC - High Performance Liquid Chromatography

IC - Ion Chromatography

ICP-ES - Inductively Coupled Plasma - Emission Spectrometry

ICP-MS - Inductively Coupled Plasma - Mass Spectroscopy

$\mathrm{KTPB}$ - Potassium tetraphenylborate $-\mathrm{K}\left[\mathrm{B}\left(\mathrm{C}_{6} \mathrm{H}_{5}\right)\right]_{4}$

LOD - Limit of Detection

MST - Monosodium titanate

NA - Not applicable

$\mathrm{NM}$ - Not measured

NR - Not reported

RAD - Radioactive (analytical method)

RSD - Relative Standard Deviation

SCO - Shielded Cells Operations, Savannah River National Laboratory

SRNL - Savannah River National Laboratory

SRR - Savannah River Remediation

SVOA - Semivolatile Organic Analysis

TPB - tetraphenylborate - $\left[\mathrm{B}\left(\mathrm{C}_{6} \mathrm{H}_{5}\right)\right]_{4}$

TTQAP - Task Technical and Quality Assurance Plan

TTR - Technical Task Request

TIC/TOC - Total inorganic carbon/total organic carbon analysis

Std Dev - Standard deviation (of replicated measurements)

\section{LIST OF UNITS}

$\mathrm{dpm} / \mathrm{mL}$ - Decays per minute per milliliter

$\mathrm{mg}$ - milligrams

$\mathrm{mg} / \mathrm{L}$ - Milligrams per liter

$\mathrm{mL}-$ milliliters

$\mathrm{L}-$ liters

wt \% - Weight percent (dissolved, insoluble, or total solids) 


\subsection{Introduction}

Tank 48H samples HTF-48-12-20 and HTF-48-12-24 were sent to SRNL for characterization. The first sample (2.75 liters) was retrieved on February 8, 2012 and the second sample (3.25 liters) was retrieved on February 28, 2012. Shielded Cells Operations (SCO) personnel received each sample in the same day it was retrieved. In addition Savannah River Remediation (SRR) requested selected analyses of filtrate from a past tank farm archived sample (HTF-E-05-021). SRNL had received sample HTF-E-05-021 on March 6, 2005. The results from the analyses are presented in this document, and the combined sample is referred to as HTF-48-12-20/24. The work supports the effort to demonstrate the destruction of organic material contained in the Tank 48 waste, most notably tetraphenylborate (TPB), by a CCPO process.

Characterization of these samples was specified in a Technical Task Request (TTR) and in a Task Technical Quality and Assurance Plan (TTQAP) approved by the customer. ${ }^{4,5}$ The TTR for the copper-catalyzed reaction work was also provided by the customer. ${ }^{6}$ The TTR and TTQAP directed blending of the 2012 Tank $48 \mathrm{H}$ samples for characterization and processing. ${ }^{4,5}$ An unexpected high volume of pump bearing water flowed into the tank between the samplings as discussed below. Results of the current work are compared to three past characterizations per customer request. The three characterizations were reported for samples retrieved in 2003 (HTFE-03-073 and HTF-E-03-127) ${ }^{1}, 2004$ (HTF-E-04-049 and HTF-E-04-050) ${ }^{2}$, and 2005 (HTF-E05-021) ${ }^{3}$. Sample HTF-48-12-24 filtrate results from F/H Area Laboratories are compared where available. ${ }^{7}$ A summary of findings is that free hydroxide is just at or above $1 \mathrm{M}$, carbonate is higher than seen before (1.39 M by TIC), and both slurry and filtrate densities $(\sim 1.2 \mathrm{~g} / \mathrm{mL})$ are measurably higher than 2003-2005 historical values.

At the time of the February 8, 2012 sampling (HTF-48-12-20) the Tank 48H volume was approximately 240,084 gallons (waste level 68.4 inches from the bottom of the tank). On February 28 sample HTF-48-12-24 was retrieved. The tank level was 71.8 inches and the volume was 252,018 gallons. Both samples were collected as soon as possible after mixing pump shutdown (approximately 2 minutes afterwards). The sampler was operated about 15 inches below the liquid level. The volume increase between samplings was due to pump bearing water addition into Tank 48H. Sample HTF-48-12-24 was thus 5\% more dilute than sample HTF-4812-20. The volume weighted dilution caused the composite HTF- $48-12-20 / 24$ to be $2.56 \%$ more dilute than HTF-48-12-20.

\subsection{Experimental Work}

Tank 48H samples HTF-48-12-20 and HTF-48-12-24 were mixed together in an 8-liter carboy in SRNL A-Block cell 3. The first step was to recover filtrate for density and analytical samples. Some settling of solids was allowed and duplicate $50 \mathrm{~mL}$ subsamples of mostly filtrate were removed from the carboy. The sub-samples were filtered using $150-\mathrm{mL}$ Nalgene cup filters with 0.45 micron pore size. Density measurements were taken by filling $2 \mathrm{~mL}$ density tubes and recording masses. The bulk of the filtrate samples were then diluted 1:1 with deionized water. Six $2 \mathrm{~mL}$ subsamples and a 10-mL sample were sent to Analytical Development (AD) in shielded plastic bottles. On March 21, 2012 the carboy was thoroughly agitated with a circulating pump and rotating propeller stirrer, and four $\sim 1 \mathrm{~mL}$ slurry samples were taken and placed in shielded plastic bottles. Each sample was bagged separately because of the higher radiation dose associated with unfiltered slurry. Slurry samples were also sent to AD. Blank bottles were sent to AD to check level of contamination in cells processing and analysis. 
The slurry samples were analyzed in duplicate (See Table 2). Each approximately 1-gram slurry aliquot was dried and was then fused with sodium peroxide at $675{ }^{\circ} \mathrm{C}$. Each resulting fused mass was digested with stock nitric acid and then diluted to $100 \mathrm{~mL}$ with deionized water. This method oxidizes all of the organics in the sample. This same procedure was used in the 2005 slurry sample digestion. ${ }^{3}$ The customer requested analyses of filtrate but not digested slurry for sample HTF-E-05-021.

Table 2. Analysis of Tank 48H Slurry Samples

\begin{tabular}{|c|c|c|c|c|}
\hline Analysis & "Samples & $\begin{array}{c}\text { Sample } \\
\text { Volume, } \\
\text { (each), mL }\end{array}$ & $\begin{array}{c}\text { Dilution } \\
\text { Volume, } \mathbf{m L}\end{array}$ & Diluent \\
\hline GAMMA SCAN (Cs-137) & 2 & 0.1 & \multirow{6}{*}{\multicolumn{2}{|c|}{$\begin{array}{l}2 \text { samples and a blank } \\
\text { digested in Cells, then split } \\
\text { into sub-samples for analysis }\end{array}$}} \\
\hline $\begin{array}{l}\text { RAD ICP-ES (Na, K, Ti, B, Si, } \\
\mathrm{Cu}, \mathrm{Fe}, \mathrm{RCRA} \text { metals) }\end{array}$ & 2 & 1 & & \\
\hline $\begin{array}{l}\text { RAD ICP-MS (fission products, } \\
\text { actinides, noble metals) }\end{array}$ & 2 & 1 & & \\
\hline GROSS ALPHA & 2 & 0.5 & & \\
\hline${ }^{90} \mathrm{Sr},{ }^{99} \mathrm{Tc}$ & 2 & 0.1 & & \\
\hline${ }^{238 / 241} \mathrm{Pu}$ & 2 & 0.1 & & \\
\hline VOA (Benzene) & 2 & 0.1 & 0 & None \\
\hline $\begin{array}{l}\text { SVOA (TPB decomposition } \\
\text { products) }\end{array}$ & 2 & 0.1 & 0 & None \\
\hline TOTAL SOLIDS & 3 & 3 & 0 & None \\
\hline DENSITY & 3 & 2 or 8.5 & 0 & None \\
\hline HPLC & 2 & 2 & 0 & None \\
\hline
\end{tabular}

Table 3 provides the list of methods requested for the filtrate of the composite HTF-48-12-20/24. In addition the filtrate of the SRNL archived sample of HTF-E-05-21 was analyzed by IC anions, ICP-ES, ICP-MS, and gamma scan.

Table 3. Analysis of Tank $48 \mathrm{H}$ Filtrate

\begin{tabular}{|l|c|c|c||}
\hline Analysis & Samples & $\begin{array}{c}\text { Sample } \\
\text { Volume } \\
\text { (each), mL }\end{array}$ & Diluent \\
\hline GAMMA SCAN & 2 & 0.1 & DI Water \\
\hline $\begin{array}{l}\text { TITRATION BASE/OH/OTHER } \\
\text { BASE (EXCLUDING CO3) }\end{array}$ & 2 & 1 & DI Water \\
\hline $\begin{array}{l}\text { IC ANIONS [F-, Cl', HCO }{ }^{-},(\mathrm{C} 2 \mathrm{O} 4) 2-, \\
\text { (SO4)2-, (NO3)-, (NO2)-], }\end{array}$ & 2 & 1 & DI Water \\
\hline RAD ICP-ES (Na, K, Ti, B, Si) & 2 & 2 & DI Water \\
\hline RAD ICP-MS (actinides) & 2 & 2 & DI Water \\
\hline DISSOLVED SOLIDS & 2 & 1 & None \\
\hline $\mathrm{DENSITY}$ & 2 & 5 & None \\
\hline GROSS ALPHA & 2 & 0.5 & DI Water \\
\hline${ }^{90} \mathrm{Sr},{ }^{99} \mathrm{Tc}$ & 2 & 0.1 & DI Water \\
\hline${ }^{238 / 241} \mathrm{Pu}$ & & DI Water \\
\hline
\end{tabular}


Personnel filtered approximately $50 \mathrm{~mL}$ of slurry in duplicate using $0.45 \mu \mathrm{m}$ supported acrylic copolymer disc cup filters. Each filtration provided approximately $24 \mathrm{~mL}$ of liquid. Density was measured at this point with $2-\mathrm{mL}$ density tubes and an analytical balance. Filtrate was added to a $60 \mathrm{~mL}$ plastic bottle with a pre-measured $25 \mathrm{~mL}$ of deionized (DI) water (yielding slightly more than 2:1 dilution). The contents of the plastic bottle were well mixed by vigorously shaking and checked for solids. The liquid was then distributed into shielded plastic bottles for transfer to AD. Physical properties were measured in a shielded cell. The TTQAP cites the relevant AD procedures for this work. ${ }^{5}$

\subsection{Results and Discussion}

The HTF-48-12-20/24 slurry results are reported in units of $\mathrm{mg} / \mathrm{L}$ of slurry and the filtrate results in units of $\mathrm{mg} / \mathrm{L}$ filtrate. Radiochemical results are reported in $\mathrm{dpm} / \mathrm{mL}$ of slurry or filtrate. Historical results are referred to by sample number and 2003, 2004, and 2005 report as cited. No analyses of the archived HTF-E-05-21 slurry were requested or performed. Section 3.2 includes analyses of archived HTF-E-05-21 filtrate.

\subsection{Slurry Sample Results for the HTF-48-12-20/24 Composite}

\subsubsection{Radionuclide Composition in Slurry}

Gamma scan was used to determine the ${ }^{137} \mathrm{Cs}$ content of slurry after peroxide fusion digestion and nitric acid uptake. Separation and beta counting results for ${ }^{99} \mathrm{Tc}$ and ${ }^{90} \mathrm{Sr}$ are also reported here and compared to previous characterizations. Results are provided in Table 4. Duplicate results for ${ }^{99} \mathrm{Tc},{ }^{90} \mathrm{Sr}$, and gross alpha were $<4.58 \mathrm{E}+04,<4.26 \mathrm{E}+05$, and $<2.90 \mathrm{E}+05 \mathrm{dpm} / \mathrm{mL}$ upper limits, respectively, because interference or other problems prevented quantification. The current work quantified ${ }^{238} \mathrm{Pu}$ and that concentration (activity) should be used for gross alpha as well.

Table 4. Slurry Radionuclide Composition Data, dpm/mL

\begin{tabular}{|c|c|c|c|c||}
\hline $\begin{array}{c}\text { Radionuclide, } \\
\text { dpm/mL }\end{array}$ & $\begin{array}{c}\text { HTF-48-12- } \\
20 / 24\end{array}$ & HTF-E-05-21 & $\begin{array}{c}\text { HTF-E-04-049 } \\
\text { and HTF-E-04- } \\
050^{2}\end{array}$ & HTF-E-03-127 \\
\hline${ }^{137} \mathrm{Cs}$ & $\begin{array}{c}7.81 \mathrm{E}+08 \pm \\
3.9 \mathrm{E}+07\end{array}$ & $\begin{array}{c}7.53 \mathrm{E}+08 \pm \\
2.5 \mathrm{E}+07\end{array}$ & $\begin{array}{c}9.05 \mathrm{E}+08 \pm \\
1.1 \mathrm{E}+07\end{array}$ & $\begin{array}{c}1.01 \mathrm{E}+09 \pm \\
5.0 \mathrm{E}+06\end{array}$ \\
\hline${ }^{99} \mathrm{Tc}$ & $4.65 \mathrm{E}+04^{*}$ & $\mathrm{NM}$ & $\mathrm{NM}$ & $\mathrm{NM}$ \\
\hline${ }^{90} \mathrm{Sr}$ & $1.37 \mathrm{E}+05^{*}$ & $\mathrm{NM}$ & $\mathrm{NM}$ & $\begin{array}{c}1.63 \mathrm{E}+05 \pm \\
1.4 \mathrm{E}+04\end{array}$ \\
\hline${ }^{238} \mathrm{Pu}$ & $\begin{array}{c}3.13 \mathrm{E}+05 \pm \\
1.6 \mathrm{E}+04\end{array}$ & $\mathrm{NM}$ & $\mathrm{NM}$ & $\mathrm{NM}$ \\
\hline${ }^{239 / 240} \mathrm{Pu}$ & $<6.74 \mathrm{E}+02$ & $\mathrm{NM}$ & $\mathrm{NM}$ & $\mathrm{NM}$ \\
\hline${ }^{241} \mathrm{Pu}$ & $<1.66 \mathrm{E}+04$ & $\mathrm{NM}$ & $\mathrm{NM}$ & $\mathrm{NM}$ \\
\hline Gross Alpha & $<2.88 \mathrm{E}+05^{*}$ & $\mathrm{NM}$ & $\begin{array}{c}1.01 \mathrm{E}+04 \pm \\
7.0 \mathrm{E}+02\end{array}$ & $\begin{array}{c}2.80 \mathrm{E}+05 \pm \\
4.0 \mathrm{E}+03\end{array}$ \\
\hline \hline
\end{tabular}

* Second measurements were upper limit values, see text

$\mathrm{NM}=$ not measured 
Americium, curium, and californium measurements are provided in Table 5 below. Characterization of samples in the past have always found these isotopes to be less than detectable, so no comparisons are available. In contrast this current characterization of sample HTF-48-12-20/24 was able to detect and report ${ }^{241} \mathrm{Am}$ content. The analytical procedure provides unique LOD values from each measurement as shown in the table.

Table 5. Americium, Curium, and Californium in HTF-48-12-20/24 Slurry

\begin{tabular}{|c|c|c|c|}
\hline Analyte & $\begin{array}{l}\text { First Slurry } \\
\text { Sample } \\
\text { dpm/mL slurry }\end{array}$ & $\begin{array}{l}\text { Second Slurry } \\
\text { Sample } \\
\text { dpm/mL slurry }\end{array}$ & $\begin{array}{l}\text { Average and Std Dev } \\
\mathrm{dpm} / \mathrm{mL} \text { slurry }\end{array}$ \\
\hline${ }^{241} \mathrm{Am}$ & $6.08 \mathrm{E}+03$ & $4.91 \mathrm{E}+03$ & $5.50 \pm 0.830 \mathrm{E}+03$ \\
\hline${ }^{243} \mathrm{Am}$ & $<2.44 \mathrm{E}+03$ & $<2.29 \mathrm{E}+02$ & NA \\
\hline${ }^{242 \mathrm{~m}} \mathrm{Am}$ & $<3.56 \mathrm{E}+02$ & $<3.81 \mathrm{E}+01$ & NA \\
\hline${ }^{243} \mathrm{Cm}$ & $<8.44 \mathrm{E}+02$ & $<8.37 \mathrm{E}+02$ & NA \\
\hline${ }^{245} \mathrm{Cm}$ & $<6.91 \mathrm{E}+03$ & $<6.86 \mathrm{E}+02$ & NA \\
\hline${ }^{247} \mathrm{Cm}$ & $<4.68 \mathrm{E}+03$ & $<2.03 \mathrm{E}+03$ & NA \\
\hline${ }^{249} \mathrm{Cf}$ & $<5.25 \mathrm{E}+03$ & $<2.03 \mathrm{E}+03$ & NA \\
\hline${ }^{251} \mathrm{Cf}$ & $<4.76 \mathrm{E}+03$ & $<2.20 \mathrm{E}+03$ & NA \\
\hline${ }^{242} \mathrm{Cm}$ & $<2.96 \mathrm{E}+02$ & $<3.16 \mathrm{E}+01$ & $\overline{\mathrm{NA}}$ \\
\hline${ }^{244} \mathrm{Cm}$ & $<1.14 \mathrm{E}+03$ & $<2.36 \mathrm{E}+03$ & NA \\
\hline
\end{tabular}

\subsubsection{Inductively Coupled Plasma Emission Spectroscopy (ICP-ES) for Digested Slurry}

Table 6 presents the elemental composition (in $\mathrm{mg} / \mathrm{L}$ of slurry) of the digested slurry by ICP-ES. The digestion method (sodium peroxide fusion in a zirconium crucible) masked the true concentration of sodium and zirconium in the slurry. Calcium, iron, magnesium, and strontium were found at significant levels in the duplicate sample blanks as shown in Table 7. The blank results indicate that concentrations of these four elements in Table 6 are likely from sample preparation rather than sample content.

AD personnel used about $100 \mathrm{~mL}$ of dilute nitric acid per gram of slurry for digestion and dilution. This dilution tends to raise LODs. LOD values for the current work are the lower of the duplicate LOD results, and this convention is used where needed in the rest of this report.

The major constituents in the slurry include $\mathrm{Na}, \mathrm{K}, \mathrm{Al}, \mathrm{Ti}, \mathrm{Cr}$, and $\mathrm{B}$. Titanium represents 0.1535 $\pm 0.0012 \mathrm{wt} \%$ monosodium titanante (MST). This value is in agreement with the 2005 report $(0.15+/-0.01 \mathrm{wt} \% \mathrm{MST})$ and 2004 report $(0.15+/-0.015 \mathrm{wt} \% \mathrm{MST}){ }^{2,3}$ The 2003 report provided a slightly lower MST concentration of $0.14+/-0.0025 \mathrm{wt} \%{ }^{1}$

Boron concentrations were in line with measurements of past samples. Aluminum and potassium were measurably higher than concentrations found in previous samples. Chromium, which tends to be present as chromate in most waste supernate, was lower and was below detection in contrast to concentrations found in past samples. However, the current filtrate chromium concentration shown in Table 18 is $42 \mathrm{mg} / \mathrm{L}$, indicating that soluble chromium is in line with expectations. Filtrate chromium is thus considered representative. 
SRNL-STI-2012-00420

Revision 0

Table 6. Comparison of ICP-ES Data for Slurry Samples

\begin{tabular}{|c|c|c|c|c|}
\hline Component & $\begin{array}{c}\text { HTF-48-12- } \\
20 / 24 \\
\text { mg/L of slurry } \\
\end{array}$ & $\begin{array}{l}\text { HTF-E- } 05-21 \\
\mathrm{mg} / \mathrm{L} \text { of slurry }\end{array}$ & $\begin{array}{c}\text { HTF-E-04-049 and } \\
\text { HTF-E-04-050 } \\
\text { mg/L of slurry }\end{array}$ & $\begin{array}{l}\text { HTF-E-03-127 } \\
\text { mg/L of slurry }\end{array}$ \\
\hline $\mathrm{Ag}$ & $<225$ & $<0.01$ & NR & $\mathrm{NR}$ \\
\hline $\mathrm{Al}$ & $3110 \pm 387$ & 2014 & 2240 & 2030 \\
\hline $\mathrm{B}$ & $1070 \pm 49$ & 867 & 1030 & 987 \\
\hline $\mathrm{Ba}$ & $<20$ & $<0.008$ & 2.52 & 3.47 \\
\hline $\mathrm{Be}$ & $<5$ & NM & NR & NR \\
\hline $\mathrm{Ca}$ & $606 \pm 121^{*}$ & 43 & 21.4 & 19.7 \\
\hline $\mathrm{Cd}$ & $<28$ & $<0.017$ & NR & NR \\
\hline $\mathrm{Ce}$ & $<166$ & 5 & 7 & NR \\
\hline $\mathrm{Cr}$ & $74 \pm 3$ & 70 & 51 & 46.6 \\
\hline $\mathrm{Cu}$ & $<13$ & 4 & 3 & 1.97 \\
\hline $\mathrm{Fe}$ & $159 *$ & 169 & 43 & 53.9 \\
\hline $\mathrm{Gd}$ & $<41$ & $<0.01$ & NR & NR \\
\hline $\mathrm{K}$ & $3230 \pm 220$ & 2658 & 2380 & 2570 \\
\hline $\mathrm{La}$ & $<24$ & $<0.032$ & NR & NR \\
\hline $\mathrm{Li}$ & $<32$ & $<0.026$ & NR & 0.99 \\
\hline $\mathrm{Mg}$ & $27 \pm 5^{*}$ & 19 & 18.5 & 20.2 \\
\hline $\mathrm{Mn}$ & $10.6 \pm 0.1$ & 6 & 6.38 & 7.82 \\
\hline Mo & $<235$ & $<0.053$ & 13.3 & 9.19 \\
\hline $\mathrm{Na}$ & NA & NM & 74900 & 64600 \\
\hline $\mathrm{Ni}$ & $<86.2$ & $<0.015$ & NR & NR \\
\hline $\mathrm{P}$ & $<482$ & 129 & 207 & 192 \\
\hline $\mathrm{Pb}$ & $<373$ & $<0.283$ & NR & NR \\
\hline $\mathrm{S}$ & $<1130$ & 378 & 245 & 259 \\
\hline $\mathrm{Sb}$ & $<763$ & $<0.042$ & 11.5 & 8.45 \\
\hline $\mathrm{Si}$ & $<452$ & 125 & 106 & 89.9 \\
\hline $\mathrm{Sn}$ & $<310$ & $<0.11$ & 22.1 & NR \\
\hline $\mathrm{Sr}$ & $5.27 \pm 0.59 *$ & 9 & 5.29 & 5.64 \\
\hline $\mathrm{Ti}$ & $897 \pm 7$ & 826 & 840 & 776 \\
\hline $\mathrm{U}$ & $<<1230$ & 7 & 17.6 & NR \\
\hline $\mathrm{V}$ & $<11$ & $<0.007$ & NR & NR \\
\hline $\mathrm{Zn}$ & $<28$ & 5 & 12 & 7.91 \\
\hline $\mathrm{Zr}$ & NA & 1.47 & NR & NR \\
\hline
\end{tabular}

*Sample blanks showed significant concentrations of these elements. $\quad$ NR $=$ Not reported 


\section{Table 7. Results from Peroxide Fusion Blanks for ICP-ES}

\begin{tabular}{|c|c|c|}
\hline Component & Blank 3-297687 & Blank 3-298993 \\
\hline $\mathrm{Ca}$ & 2000 & 1870 \\
\hline $\mathrm{Fe}$ & $<158$ & 336 \\
\hline $\mathrm{Mg}$ & 11.2 & 47.2 \\
\hline $\mathrm{Sr}$ & 17.6 & 16.8 \\
\hline
\end{tabular}

\subsubsection{Inductively Coupled Plasma Mass Spectroscopy (ICP-MS)}

Table 8 presents analyses of Tank 48H (HTF-48-12-20/24) slurry for some heavy elements. Uranium and neptunium concentrations are in line with past measurements. The mass data for ${ }^{99} \mathrm{Tc}$ translates to $7.5 \mathrm{E}+04 \mathrm{dpm} / \mathrm{mL}$ which is $50 \%$ higher than the radiochemical measurements for the slurry (Table 4) and filtrate (Table 17). Radiochemical measurements for technetium are considered more reliable. Mercury was not reported because the digestion process reached at least $670^{\circ} \mathrm{C}$. At this temperature, we expect mercury to volatize.

Table 8. ICP-MS Data for Slurry

\begin{tabular}{|c|c|c|c|c|}
\hline $\begin{array}{c}\text { Mass and } \\
\text { Isotope }\end{array}$ & $\begin{array}{c}\text { HTF-48-12-20/24 } \\
\text { (mg/L slurry) }\end{array}$ & $\begin{array}{c}2005 \\
\text { HTF-E-05-21 } \\
(\mathrm{mg} / \mathrm{L} \text { slurry })^{3}\end{array}$ & $\begin{array}{c}\text { HTF-E-04-049 and } \\
\text { HTF-E-04-050 } \\
(\mathrm{mg} / \mathrm{L} \text { slurry })^{2}\end{array}$ & $\begin{array}{c}\text { HTF-E-03-073 and } \\
\text { HTF-E-03-127 } \\
\text { (mg/L slurry })^{1}\end{array}$ \\
\hline${ }^{99} \mathrm{Tc}$ & $2.0 \pm 0.73$ & $1.23 \pm 0.08$ & $\mathrm{NR}$ & $\mathrm{NM}$ \\
\hline${ }^{133} \mathrm{Cs}$ & $15.0 \pm 1.62$ & $\mathrm{NR}$ & $\mathrm{NR}$ & $\mathrm{NR}$ \\
\hline${ }^{233} \mathrm{U}$ & $<0.118^{*}$ & $<0.09$ & $0.0613 \pm 0.00739$ & $0.0696 \pm 0.00131$ \\
\hline${ }^{234} \mathrm{U}$ & $0.31^{*}$ & $0.267 \pm 0.012$ & $0.325 \pm 0.0194$ & $\mathrm{NR}$ \\
\hline${ }^{235} \mathrm{U}$ & $0.73^{*}$ & $0.564 \pm 0.050$ & $0.653 \pm 0.0443$ & $0.653 \pm 0.0201$ \\
\hline${ }^{236} \mathrm{U}$ & $0.19^{*}$ & $0.125 \pm 0.006$ & $0.144 \pm 0.00485$ & $\mathrm{NR}$ \\
\hline${ }^{237} \mathrm{~Np}$ & $0.33^{*}$ & $0.173 \pm 0.040$ & $0.222 \pm 0.0081$ & $0.229 \pm 0.00369$ \\
\hline${ }^{238} \mathrm{U}$ & $5.32 \pm 1.60$ & $3.32 \pm 0.359$ & $4.12 \pm 0.224$ & $4.04 \pm 0.0595$ \\
\hline \hline
\end{tabular}

* Second measurements were $<2.07 \mathrm{mg} / \mathrm{L} \quad \mathrm{NR}=$ Not reported

\subsubsection{Volatile and Semivolatile Organic Analyses for Slurry}

Semivolatile organic analysis (SVOA) and volatile organic analysis (VOA) are used to detect aromatic compounds including breakdown products from TPB. The SVOA and VOA results from the slurry sample for the HTF-48-12-20/24 sample are shown in Table 9. Also shown in Table 9 are the results of similar compounds in the 2005 HTF-E-05-021 sample. The 2004 report for HTF-E-04-049 and HTF-E-04-050 samples did not run VOA or SVOA on slurry. ${ }^{2}$ The 2003 characterization is not in Table 9 because it reported no significant SVOA analytes, and VOA at the time measured benzene at $56 \pm 12 \mathrm{mg} / \mathrm{L}^{1}$

Slurry samples for SVOA are first extracted with hexane. The organic extract is analyzed with a gas chromatograph and mass spectrometer. The VOA preparation in contrast uses a purge and 
trap system where the aqueous sample (slurry) has an inert gas bubbled through it. The gas is likewise analyzed with a gas chromatograph and mass spectrometer.

The analysis results indicate the presence of nitro-aromatic compounds and other condensed ring compounds. If no standard deviation value is given then the compound was detected in only one of the two analyzed samples. Although nitro-aromatic compounds are energetic, their low concentrations observed here will not result in a significant temperature rise or gas generation upon decomposition.

The diisooctyl adapate is not an aromatic species and is not expected. This compound assignment may be an artifact of the SVOA compound identification method or additives from contact with plastic. Volatile analysis indicates the presence of benzene in the slurry. Benzene is a by-product from the decomposition of TPB and its degradation products. The wide error band is due to the tendency of benzene to vaporize from aqueous material.

Table 9. VOA and SVOA Analyses for Slurry

\begin{tabular}{||l|c|c|}
\hline \multicolumn{1}{|c|}{ Component } & $\begin{array}{c}\text { HTF-48-12-20/24 } \\
\mathrm{mg} / \mathrm{L}\end{array}$ & $\begin{array}{c}\text { HTF-E-05-021 } \\
(\mathrm{mg} / \mathrm{L} \text { slurry })^{3}\end{array}$ \\
\hline Biphenyl & $925 \pm 106$ & $414.6 \pm 106$ \\
\hline Nitrobenzene & $100^{*}$ & $180.6 \pm 104$ \\
\hline 2-Nitrophenol & $130^{*}$ & $\mathrm{ND}$ \\
\hline 4-Nitrophenol & $120^{*}$ & $\mathrm{ND}$ \\
\hline m-Terphenyl & $25 \pm 17$ & $\mathrm{ND}$ \\
\hline p-Terphenyl & $30.5 \pm 3.54$ & $\mathrm{ND}$ \\
\hline Diisooctyl Adapate & $170^{*}$ & $64.3 \pm 32.7$ \\
\hline $\begin{array}{l}\text { 1-Ethyldisopropyl } \\
\text { Benzene }\end{array}$ & $<1$ & $25.3 \pm 5.4$ \\
\hline Nitrosobenzene & $170^{*}$ & $17.9 \pm 1.0$ \\
\hline Benzene** & $49.2 \pm 66.3$ & \multicolumn{2}{|c|}{} \\
\hline $\begin{array}{l}* \text { Only one measurement provided a concentration for this compound } \\
* * \text { Values of } 96 \text { and 2.3 mg/L were measured for the current sample }\end{array}$ \\
\hline
\end{tabular}

\subsubsection{High Performance Liquid Chromatography (HPLC)}

Personnel measured the concentration of tetraphenylborate and its degradation products in the HTF-48-12-20/24 slurry sample by HPLC. Table 10 lists the HPLC results for the slurry. The analytical method is considered more sensitive to organic anion measurement than the SVOA method. TPB, KTPB, and phenol concentrations, as shown in Table 10, are consistent with previous measurements.

HPLC provides the four phenylboron compounds found in Tank $48 \mathrm{H}$ slurry. The duplicate tetraphenylborate measurements provided the same value as indicated by the zero standard deviation. KTPB is calculated by multiplying the TPB anion value by the ratio of the KTPB/TPB molecular weights. No error is given because the anion duplicates were in agreement. The detection limits for the duplicate measurements for phenol, triphenylboron (3PB), diphenylboronic acid (2PB), and phenylborinic acid (1PB) were above the measured values shown, so no standard deviation is given. 
SRNL-STI-2012-00420

Revision 0

Table 10. HPLC Data for Slurry

\begin{tabular}{|l|c|c|c|c||}
\hline Analyte & $\begin{array}{c}\text { HTF-48-12- } \\
20 / 24 \\
\mathrm{mg} / \mathrm{L}\end{array}$ & $\begin{array}{c}\text { HTF-E-05-21 } \\
\mathrm{mg} / \mathrm{L}^{3}\end{array}$ & $\begin{array}{c}\text { HTF-E-04-049 } \\
\text { and HTF-E-04- } \\
050 \\
\mathrm{mg} / \mathrm{L}^{2}\end{array}$ & $\begin{array}{c}\text { HTF-E-03-073 and } \\
\text { HTF-E-03-127 } \\
\mathrm{mg} / \mathrm{L}^{1}\end{array}$ \\
\hline TPB Anion & $19000 \pm 0$ & $21000 \pm 970$ & $20100 \pm 235$ & $18800 \pm 1120$ \\
\hline $\begin{array}{l}\text { Calculated } \\
\text { KTPB }\end{array}$ & 21300 & 23796 & $22600 \pm 263$ & $21100 \pm 1250$ \\
\hline Phenol & $609^{*}$ & $771 \pm 22$ & $735 \pm 24$ & $973 \pm 165$ \\
\hline 3PB & $100^{*}$ & $74 \pm 16.5$ & $162 \pm 35$ & $<50$ \\
\hline 2PB & $200^{*}$ & $142 \pm 19$ & $123 \pm 6.1$ & $<50$ \\
\hline 1PB & $180^{*}$ & $151 \pm 7.6$ & $120 \pm 5.6$ & $<50$ \\
\hline
\end{tabular}

* Second measurements were below detection $(<5000 \mathrm{mg} / \mathrm{L})$

\subsubsection{Total Base, Organic and Inorganic Carbon}

Table 11 contains the total base, free hydroxide, and other base data for the February 2012 slurry. There are no historical results using this analysis method on slurry that is available for comparison. The current results have a very high variation and this may be caused by the presence of the slurry solids interfering with the titration method.

Table 11. Total, Free and Other Base Content of Slurry

\begin{tabular}{|c|c|}
\hline \hline Analyte & HTF-48-12-20/24 \\
\hline & $\mathrm{M}$ \\
\hline Total Base & $1.85 \pm 0.849$ \\
\hline Free OH- & $0.652 \pm 0.229$ \\
\hline Other Base & $0.1 \pm 0.117$ \\
\hline
\end{tabular}

\subsection{HTF-48-12-20/24 Composite Filtrate Sample Results}

AD personnel analyzed duplicate Tank 48H HTF-48-12-20/24 filtrate samples. Personnel removed samples of the Tank $48 \mathrm{H}$ filtrate from the Shielded Cells after approximately 2:1 dilution with DI water. The analytical data is reported together with the one standard deviation $(1 \sigma)$ uncertainty. To compare the slurry results with the filtrate results, the filtrate result would be multiplied by a factor of 1.0026 to convert to a slurry basis. This factor is the ratio of filtrate mass $(\mathrm{mg} / \mathrm{L})$ to slurry mass $(\mathrm{mg} / \mathrm{L})$. It is calculated by the following formula:

filtrate correction factor $=$ slurry density $*(1$-insoluble solids $) /$ density filtrate

$$
=1.219 *(1-0.01467) / 1.198=1.0026
$$

Given that the factor is so close to unity it was not applied to adjust any results. 


\subsubsection{IC Anions, Total Base, and Organic and Inorganic Carbon}

AD personnel analyzed the HTF-48-12-20/24 filtrate samples using titration methods and density measurements. The HTF-48-12-20/24 total base concentration is $2.56 \pm 0.02 \mathrm{M}$ and the free hydroxide is $1.02 \pm 0.02 \mathrm{M}$. The concentration of other bases is $0.1 \pm 0.09 \mathrm{M}$ and carbonate concentration is $16646 \mathrm{mg} / \mathrm{L}$ carbon $(1.385 \pm 0.01 \mathrm{M}$ carbonate). Historical results from 2003, 2004, and 2005 included carbonate (not TIC) measurement. ${ }^{1,2,3}$ These are converted to a carbon basis and are shown for comparison in the TIC row of Table 12. The 2003 report also did include TIC and this is provided in Table 12 as well. ${ }^{1}$ All historical data show that carbonate is now more than twice the past measured concentrations. A combination of carbon dioxide adsorbed from the air in Tank $48 \mathrm{H}$ and organic degradation over the years may explain this. Table 12 lists the IC anions results for the archived HTF-E-05-021 sample, but no titration or TIC/TOC work had been requested or performed for that sample.

The free hydroxide concentration (at $1.34 \mathrm{M}$ ) had increased since the September 2003 sampling $(0.790 \mathrm{M})$ due to the addition of sodium hydroxide in October 2003 and December 2004. The current free hydroxide concentration shows a decline with time after 2005. The increase in carbonate suggests that breakdown of organic chemicals may have converted free hydroxide to carbonate.

Table 12. Anion, Base and Carbon Content of Filtrate

\begin{tabular}{|c|c|c|c|c|c|}
\hline Analyte & $\begin{array}{c}\text { HTF-48-12- } \\
20 / 24 \\
\mathrm{mg} / \mathrm{L}\end{array}$ & $\begin{array}{c}\text { Cells } \\
\text { Archived } \\
\text { HTF-E-05-21 } \\
\text { mg/L }\end{array}$ & $\begin{array}{c}2005 \\
\text { HTF-E-05-21 } \\
\text { mg/L }\end{array}$ & $\begin{array}{c}\text { HTF-E-04- } \\
049 \text { and HTF- } \\
\text { E-04-050² } \\
\text { mg/L }\end{array}$ & $\begin{array}{c}\text { HTF-E-03-127 } \\
\mathrm{mg} / \mathrm{L}\end{array}$ \\
\hline $\mathrm{F}^{-}$ & $<204$ & $<200$ & $14 \pm 0$ & $<20$ & $<18$ \\
\hline $\mathrm{Cl}^{-}$ & $187 \pm 16$ & $854 \pm 66$ & $172 \pm 23$ & $370 \pm 183$ & $125 \pm 5.7$ \\
\hline $\mathrm{HCOO}^{-}$ & $296 \pm 5$ & $386 \pm 5$ & $502 \pm 10$ & $680 \pm 428$ & $432 \pm 27$ \\
\hline $\mathrm{NO}_{2}^{-}$ & $24500 \pm 894$ & $26000 \pm 1202$ & $23750 \pm 350$ & $30400 \pm 1800$ & $21400 \pm 1380$ \\
\hline $\mathrm{NO}_{3}^{-}$ & $11100 \pm 1439$ & $13100 \pm 1063$ & $14250 \pm 150$ & $18750 \pm 926$ & $13400 \pm 893$ \\
\hline $\mathrm{PO}_{4}{ }^{2-}$ & $465 \pm 75$ & $682 \pm 11$ & $428 \pm 9$ & $916 \pm 222$ & $515 \pm 23.5$ \\
\hline $\mathrm{SO}_{4}{ }^{2-}$ & $209 \pm 45$ & $214 \pm 4$ & $323 \pm 1$ & $528 \pm 210$ & $273 \pm 11.4$ \\
\hline \multirow[t]{2}{*}{$\mathrm{C}_{2} \mathrm{O}_{4}{ }^{2-}$} & $1585 \pm 5$ & $1755 \pm 148$ & $1440 \pm 10$ & $1613 \pm 116$ & $1080 \pm 45.5$ \\
\hline & Molarity & & Molarity & Molarity & Molarity \\
\hline Total Base & $2.56 \pm 0.02$ & NM & $2.485 \pm 0.05$ & $2.04 \pm 0.071$ & $1.755 \pm 0.035$ \\
\hline Free OH- & $1.02 \pm 0.02$ & NM & $1.34 \pm 0.014$ & $1.155 \pm 0.007$ & $0.790 \pm 0.008$ \\
\hline \multirow[t]{2}{*}{ Other Base } & $0.1 \pm 0.09$ & NM & $0.172 \pm 0.023$ & $0.185 \pm 0.004$ & $0.267 \pm 0.038$ \\
\hline & $\mathrm{mg} / \mathrm{L}$ as $\mathrm{C}$ & & $\mathrm{mg} / \mathrm{L}$ as $\mathrm{C}$ & $\mathrm{mg} / \mathrm{L}$ as $\mathrm{C}$ & $\mathrm{mg} / \mathrm{L}$ as $\mathrm{C}$ \\
\hline $\begin{array}{c}\text { Total } \\
\text { Inorganic } \\
\text { Carbon (TIC) }\end{array}$ & $16646 \pm 347$ & NM & $\begin{array}{l}4630 \text { from } \\
\text { carbonate }\end{array}$ & $\begin{array}{l}5900 \text { from } \\
\text { carbonate }\end{array}$ & $7840 \pm 212 * *$ \\
\hline $\begin{array}{l}\text { Total Organic } \\
\text { Carbon (TOC) }\end{array}$ & $1887 \pm 358$ & NM & NM & $\mathrm{NM}$ & $3010 \pm 283$ \\
\hline Total Carbon & $18512 \pm 16$ & NM & $\mathrm{NM}$ & $\mathrm{NM}$ & $10850 \pm 71$ \\
\hline
\end{tabular}

*The duplicate result is below the LOD for that analysis

$* *$ Carbonate on this sample was reported as $5600 \pm 17 \mathrm{mg} / \mathrm{L} \mathrm{C}$ (as carbon only) 
F/H Area Laboratory Services (F/H ALS) had performed IC anions, total gamma, free hydroxide, and density of solids-free liquid from sample HTF-48-12-24 separately from the HTF-48-12$20 / 24$ composite. $^{7}$ Free hydroxide was reported to be $1.0061 \mathrm{M}$, in good agreement with the current work, and also very close to the tank corrosion limit of $1 \mathrm{M}$. Table 13 below shows that IC anions results agree except that sulfate, a minor component, shows more than $10 \%$ variance.

Table 13. Comparison of IC Anions Results with Those of F/H Lab

\begin{tabular}{|c|c|c|}
\hline Analyte & $\begin{array}{c}\text { HTF-48-12-20/24 } \\
\mathrm{mg} / \mathrm{L}(\mathrm{SRNL})\end{array}$ & $\begin{array}{c}\text { HTF-48-12-24 } \\
\mathrm{mg} / \mathrm{L} \text { (F/H ALS) }\end{array}$ \\
\hline $\mathrm{Cl}^{-}$ & $187 \pm 16$ & 199 \\
\hline $\mathrm{NO}_{2}^{-}$ & $24500 \pm 894$ & 26460 \\
\hline $\mathrm{NO}_{3}^{-}$ & $11100 \pm 1439$ & 11560 \\
\hline $\mathrm{SO}_{4}{ }^{2-}$ & $209 \pm 45$ & 298 \\
\hline
\end{tabular}

\subsubsection{Filtrate Mercury by Cold Vapor Atomic Absorption}

Total mercury in duplicate filtrate samples was found to be below detection. The detection limit for mercury is $0.2 \mathrm{mg} / \mathrm{L}$. Mercury was not measured for filtrate in the HTF-E-04-049, HTF-E-04050, and HTF-E-05-21 samples.

\subsubsection{Inductively Coupled Plasma Mass Spectroscopy of Filtrate}

Table 14 provides isotope data determined by ICP-MS of filtrate. While the measurement of ${ }^{99} \mathrm{Tc}$ by radiochemistry is preferred (Section 3.2.4), the conversion of the radiochemical value provides $1.334 \mathrm{mg} / \mathrm{L}$, which is within experimental error of the radiochemistry value.

Table 14. ICP-MS Data for HTF-48-12-20/24 Filtrate

\begin{tabular}{|c|c|c|c||}
\hline Analyte & $\begin{array}{c}\text { First Filtrate } \\
\text { Sample } \\
\mathrm{mg} / \mathrm{L}\end{array}$ & $\begin{array}{c}\text { Second Filtrate } \\
\text { Sample } \\
\mathrm{mg} / \mathrm{L}\end{array}$ & $\begin{array}{c}\text { Average } \\
\mathrm{mg} / \mathrm{L}\end{array}$ \\
\hline${ }^{99} \mathrm{Tc}$ & $1.52 \mathrm{E}+00$ & $1.51 \mathrm{E}+00$ & $1.51 \pm 0.0234 \mathrm{E}+00$ \\
\hline${ }^{133} \mathrm{Cs}$ & $4.326 \mathrm{E}-01$ & $4.264 \mathrm{E}-01$ & $4.29 \mathrm{E}-01 \pm 4.41 \mathrm{E}-03$ \\
\hline${ }^{233} \mathrm{U}$ & $1.201 \mathrm{E}-02$ & $1.614 \mathrm{E}-02$ & $1.41 \mathrm{E}-02 \pm 2.92 \mathrm{E}-03$ \\
\hline${ }^{234} \mathrm{U}$ & $7.107 \mathrm{E}-02$ & $8.262 \mathrm{E}-02$ & $7.68 \mathrm{E}-02 \pm 8.17 \mathrm{E}-03$ \\
\hline${ }^{235} \mathrm{U}$ & $1.306 \mathrm{E}-01$ & $1.530 \mathrm{E}-01$ & $1.42 \mathrm{E}-01 \pm 1.58 \mathrm{E}-02$ \\
\hline${ }^{236} \mathrm{U}$ & $3.296 \mathrm{E}-02$ & $3.876 \mathrm{E}-02$ & $3.59 \mathrm{E}-02 \pm 4.10 \mathrm{E}-03$ \\
\hline${ }^{237} \mathrm{~Np}$ & $2.946 \mathrm{E}-02$ & $3.284 \mathrm{E}-02$ & $3.12 \mathrm{E}-02 \pm 2.39 \mathrm{E}-03$ \\
\hline${ }^{238} \mathrm{U}$ & $7.498 \mathrm{E}-01$ & $8.180 \mathrm{E}-01$ & $7.84 \mathrm{E}-01 \pm 4.82 \mathrm{E}-02$ \\
\hline
\end{tabular}

Tables 15 and 16 provide comparisons of the current ICP-MS results with the 2005 archived sample HTF-E-05-21 and other historical measurements. The current uranium measurements are consistent with the archived, 2005, and 2003 work. Uranium concentration reported in the 2004 samples is consistently higher than the other analyses including the current ones. 
SRNL-STI-2012-00420

Revision 0

Table 15. Comparison of Current Filtrate ICP-MS Data with the 2005 Sample

\begin{tabular}{|c|c|c|c||}
\hline Analyte & $\begin{array}{c}\text { HTF-48-12-20/24 } \\
\mathrm{mg} / \mathrm{L}\end{array}$ & $\begin{array}{c}\text { Cells Archived HTF-E-05-21 } \\
\mathrm{mg} / \mathrm{L}\end{array}$ & $\begin{array}{c}2005 \\
\text { HTF-E-05-2 } \\
\text { mg/L }\end{array}$ \\
\hline${ }^{133} \mathrm{Cs}$ & $4.29 \mathrm{E}-01 \pm 4.41 \mathrm{E}-03$ & $6.23 \mathrm{E}-01 \pm 3.75 \mathrm{E}-02$ & Not Reported \\
\hline${ }^{233} \mathrm{U}$ & $1.41 \mathrm{E}-02 \pm 2.92 \mathrm{E}-03$ & $1.51 \mathrm{E}-02 \pm 1.63 \mathrm{E}-03$ & $1.022 \mathrm{E}-02 \pm 0.18 \mathrm{E}-03$ \\
\hline${ }^{234} \mathrm{U}$ & $7.68 \mathrm{E}-02 \pm 8.17 \mathrm{E}-03$ & $6.56 \mathrm{E}-02 \pm 7.42 \mathrm{E}-03$ & $7.128 \mathrm{E}-02 \pm 2.4 \mathrm{E}-03$ \\
\hline${ }^{235} \mathrm{U}$ & $1.42 \mathrm{E}-01 \pm 1.58 \mathrm{E}-02$ & $1.24 \mathrm{E}-01 \pm 2.83 \mathrm{E}-03$ & $1.431 \mathrm{E}-01 \pm 2.8 \mathrm{E}-03$ \\
\hline${ }^{236} \mathrm{U}$ & $3.59 \mathrm{E}-02 \pm 4.10 \mathrm{E}-03$ & $3.11 \mathrm{E}-02 \pm 3.61 \mathrm{E}-03$ & $3.100 \mathrm{E}-02 \pm 0.7 \mathrm{E}-03$ \\
\hline${ }^{237} \mathrm{~Np}$ & $3.12 \mathrm{E}-02 \pm 2.39 \mathrm{E}-03$ & $2.46 \mathrm{E}-02 \pm 7.07 \mathrm{E}-04$ & $1.856 \mathrm{E}-02 \pm 0.1 \mathrm{E}-03$ \\
\hline${ }^{238} \mathrm{U}$ & $7.84 \mathrm{E}-01 \pm 4.82 \mathrm{E}-02$ & $7.69 \mathrm{E}-01 \pm 4.24 \mathrm{E}-03$ & $8.253 \mathrm{E}-01 \pm 2.8 \mathrm{E}-02$ \\
\hline
\end{tabular}

Table 16. Comparison of Current Filtrate ICP-MS Data with the 2003/2004 Samples

\begin{tabular}{|c|c|c|c|}
\hline Analyte & $\begin{array}{c}\text { HTF-48-12-20/24 } \\
\mathrm{mg} / \mathrm{L}\end{array}$ & $\begin{array}{c}\text { HTF-E-04-049 and } \\
\text { HTF-E-04-050 } \\
\mathrm{mg} / \mathrm{L}\end{array}$ & $\begin{array}{c}\text { HTF-E-03-127 } \\
\mathrm{mg} / \mathrm{L}\end{array}$ \\
\hline${ }^{133} \mathrm{Cs}$ & $4.29 \mathrm{E}-01 \pm 4.41 \mathrm{E}-03$ & Not Reported & Not Reported \\
\hline${ }^{233} \mathrm{U}$ & $1.41 \mathrm{E}-02 \pm 2.92 \mathrm{E}-03$ & $6.13 \mathrm{E}-02 \pm 7.39 \mathrm{E}-03$ & $8.22 \mathrm{E}-03 \pm 5.11 \mathrm{E}-04$ \\
\hline${ }^{234} \mathrm{U}$ & $7.68 \mathrm{E}-02 \pm 8.17 \mathrm{E}-03$ & $3.25 \mathrm{E}-01 \pm 1.94 \mathrm{E}-02$ & Not Reported \\
\hline${ }^{235} \mathrm{U}$ & $1.42 \mathrm{E}-01 \pm 1.58 \mathrm{E}-02$ & $6.53 \mathrm{E}-01 \pm 4.43 \mathrm{E}-02$ & $8.94 \mathrm{E}-02 \pm 2.20 \mathrm{E}-03$ \\
\hline${ }^{236} \mathrm{U}$ & $3.59 \mathrm{E}-02 \pm 4.10 \mathrm{E}-03$ & $1.44 \mathrm{E}-01 \pm 4.85 \mathrm{E}-03$ & Not Reported \\
\hline${ }^{237} \mathrm{~Np}$ & $3.12 \mathrm{E}-02 \pm 2.39 \mathrm{E}-03$ & $2.22 \mathrm{E}-01 \pm 8.09 \mathrm{E}-03$ & $1.81 \mathrm{E}-02 \pm 1.29 \mathrm{E}-03$ \\
\hline${ }^{238} \mathrm{U}$ & $7.84 \mathrm{E}-01 \pm 4.82 \mathrm{E}-02$ & $4.12 \mathrm{E}+00 \pm 2.24 \mathrm{E}-01$ & $5.88 \mathrm{E}-01 \pm 1.69 \mathrm{E}-02$ \\
\hline
\end{tabular}

\subsubsection{Radionuclide Composition of Filtrate}

AD personnel analyzed the filtered sample using radiochemical methods. Cesium $\left({ }^{137} \mathrm{Cs}\right)$ is the major radioactive analyte in the filtrate at a concentration of $2.57 \pm 0.026 \mathrm{E} 7 \mathrm{dpm} / \mathrm{mL}$. F/H Area Laboratory Services reported a total gamma value of $2.52 \mathrm{E}+07 \mathrm{dpm} / \mathrm{mL}$ for HTF-48-12-24 filtrate, in close agreement with the result in Table 17.

Many comparisons with past samples are not possible because previous samples had no measurement. The current filtrate sample appears to have at least one order of magnitude less soluble plutonium than the 2003 samples. 
SRNL-STI-2012-00420

Revision 0

Table 17. Comparison of Filtrate Radiochemistry Data

\begin{tabular}{||c|c|c|c|c|}
\hline $\begin{array}{c}\text { Radio } \\
\text { Isotope }\end{array}$ & $\begin{array}{c}\text { HTF-48-12-20/24 } \\
\mathrm{dpm} / \mathrm{mL}\end{array}$ & $\begin{array}{c}2005 \\
\text { HTF-E-05-21 } \\
\mathrm{dpm} / \mathrm{mL}\end{array}$ & $\begin{array}{c}\text { HTF-E-04-049 and } \\
\text { HTF-E-04-050 } \\
\text { dpm } / \mathrm{mL}\end{array}$ & $\begin{array}{c}\text { HTF-E-03-127 } \\
\text { dpm } / \mathrm{mL}\end{array}$ \\
\hline${ }^{244} \mathrm{Cm}$ & $<1.51 \mathrm{E}+01^{*}$ & $\mathrm{NM}$ & $\mathrm{NM}$ & $\mathrm{NM}$ \\
\hline${ }^{137} \mathrm{Cs}$ & $2.57 \pm 0.026 \mathrm{E}+07$ & $3.0 \pm 0.4 \mathrm{E}+07$ & $2.57 \pm 0.006 \mathrm{E}+07$ & $2.76 \pm 0.057 \mathrm{E}+07$ \\
\hline${ }^{238} \mathrm{Pu}$ & $2.89 \pm 0.183 \mathrm{E}+02$ & $\mathrm{NM}$ & $\mathrm{NM}$ & $1.69 \pm 0.195 \mathrm{E}+03$ \\
\hline${ }^{239 / 240} \mathrm{Pu}$ & $<23.1 * *$ & $\mathrm{NM}$ & $\mathrm{NM}$ & $250 . \pm 0.812$ \\
\hline${ }^{90} \mathrm{Sr}$ & $4.09 \pm 3.6 \mathrm{E}+03$ & $\mathrm{NM}$ & $\mathrm{NM}$ & $2.16 \pm 0.625 \mathrm{E}+03$ \\
\hline${ }^{99} \mathrm{Tc}$ & $5.02 \pm 0.806 \mathrm{E}+04$ & $\mathrm{NM}$ & $\mathrm{NM}$ & $8.51 \pm 1.23 \mathrm{E}+04$ \\
\hline${ }^{241} \mathrm{Pu}$ & $<7.34 \mathrm{E}+02 * *$ & $\mathrm{NM}$ & $\mathrm{NM}$ & $\mathrm{NM}$ \\
\hline $\begin{array}{c}\text { Gross } \\
\text { Alpha }\end{array}$ & $<1.93 \mathrm{E}+03 * *$ & $\mathrm{NM}$ & $2.00 \pm 0.389 \mathrm{E}+03$ & $<1.33 \mathrm{E}+04$ \\
\hline \hline
\end{tabular}

*The lowest LOD is provided when both duplicates provide LOD values.

** Upper limit values where interference prevents quantification

\subsubsection{Inductively Coupled Plasma Emission Spectroscopy of Filtrate}

AD determined the elemental composition of the filtrate by the ICP-ES method. The major constituents found in the filtrate included $\mathrm{Na}, \mathrm{Al}$, and $\mathrm{B}$, as shown in Table 18. The element sodium is present in the highest concentration at $3.74 \mathrm{M}$. Elements measured below instrument detection limits include $\mathrm{Ag}, \mathrm{Ba}, \mathrm{Cd}, \mathrm{Ce}, \mathrm{Fe}, \mathrm{Gd}, \mathrm{La}, \mathrm{Li}, \mathrm{Mg}, \mathrm{Mn}, \mathrm{Ni}, \mathrm{Pb}, \mathrm{Sn}, \mathrm{Ti}, \mathrm{U}$, and $\mathrm{Zr}$ (LOD values for these elements are listed in Table 18). The comparisons of measured elements with those of historical filtrate samples show no significant differences. 
Table 18. Comparison of Filtrate ICP-ES Data

\begin{tabular}{|c|c|c|c|c|c|}
\hline Component & $\begin{array}{c}\text { HTF-48-12- } \\
20 / 24\end{array}$ & $\begin{array}{l}\text { HTF-E-05-21 } \\
\text { archived }\end{array}$ & HTF-E-05-21 3 & $\begin{array}{c}\text { HTF-E-04- } \\
049 \text { and HTF- } \\
\text { E-04-050 }\end{array}$ & $\begin{array}{c}\text { HTF-E-03- } \\
073 \text { and HTF- } \\
\text { E-03-127 }\end{array}$ \\
\hline $\mathrm{Ag}$ & $<3.0$ & $<1.46$ & $<3$ & NR & NR \\
\hline $\mathrm{Al}$ & $2050 \pm 154$ & 2370 & 2309 & NR & 2180 \\
\hline $\mathrm{B}$ & $463 \pm 110$ & 485 & 460 & 412 & 443 \\
\hline $\mathrm{Ba}$ & $<1.3$ & $<0.52$ & $<6$ & NR & NR \\
\hline $\mathrm{Be}$ & $<0.1$ & $<0.08$ & NR & NR & NR \\
\hline $\mathrm{Ca}$ & $<1.2$ & $<0.56$ & NR & NR & 0.642 \\
\hline $\mathrm{Cd}$ & $<0.6$ & $<0.7$ & $<1$ & NR & NR \\
\hline $\mathrm{Ce}$ & $<14.6$ & $<6.03$ & $<35$ & NR & NR \\
\hline $\mathrm{Cr}$ & $42.1 \pm 6.5$ & 48. & NR & NR & 47.5 \\
\hline $\mathrm{Cu}$ & $<1.3$ & $<0.63$ & $<3$ & 1.01 & 0.617 \\
\hline $\mathrm{Fe}$ & $<2.0$ & $<0.33$ & $<3$ & NR & NR \\
\hline $\mathrm{Gd}$ & $<1.6$ & $<0.78$ & $<4$ & NR & NR \\
\hline $\mathrm{K}$ & $286 \pm 23$ & 335 & 266.7 & 373 & 248 \\
\hline $\mathrm{La}$ & $<1.1$ & $<0.54$ & $<13$ & NR & NR \\
\hline $\mathrm{Li}$ & $<3.0$ & $<1.46$ & $<12$ & NR & NR \\
\hline $\mathrm{Mg}$ & $<0.3$ & $<0.15$ & $<1$ & NR & NR \\
\hline $\mathrm{Mn}$ & $<0.4$ & $<0.21$ & $<1$ & NR & 0.036 \\
\hline Mo & $<12.7$ & $<6.26$ & NR & NR & 9.94 \\
\hline $\mathrm{Na}$ & $85800 \pm 7670$ & 86700 & 87899 & 68800 & 69300 \\
\hline $\mathrm{Ni}$ & $<3.3$ & $<1.6$ & $<10$ & NR & NR \\
\hline $\mathrm{P}$ & $<161$ & 245 & NR & NR & 241 \\
\hline $\mathrm{Pb}$ & $<15$ & $<7.16$ & NR & NR & NR \\
\hline $\mathrm{S}$ & $199 \pm 53$ & 244 & NR & NR & 280 \\
\hline $\mathrm{Sb}$ & $<22.0$ & $<10.7$ & NR & NR & 6.87 \\
\hline $\mathrm{Si}$ & $<9.0$ & 6.57 & $<125$ & 4.675 & 6.84 \\
\hline $\mathrm{Sn}$ & $<11.6$ & $<5.61$ & $<77$ & NR & 4.92 \\
\hline $\mathrm{Sr}$ & $<0.1$ & $<0.05$ & NR & NR & NR \\
\hline $\mathrm{Ti}$ & $<0.3$ & $<0.38$ & $<1$ & NR & NR \\
\hline $\mathrm{U}$ & $<67.4$ & $<32.7$ & $<50$ & NR & NR \\
\hline $\mathrm{V}$ & $<1.0$ & $<0.08$ & NR & NR & 0.889 \\
\hline $\mathrm{Zn}$ & $5.47 \pm 1.35$ & 5.97 & NR & NR & 5.41 \\
\hline $\mathrm{Zr}$ & $<0.5$ & $<0.55$ & $<2$ & NR & NR \\
\hline
\end{tabular}

The lowest LOD is provided when both duplicates provide LOD values.

\subsection{In-Cell Slurry Sample Results}

Personnel measured solids contents and densities in the Shielded Cells because of the high activity of the samples. 


\subsubsection{Slurry and Filtrate Density}

Filtrate from the Nalgene ${ }^{\circledR}$ cup filters was checked for visible solids, and none were seen in all cases for this work. Table 19 shows that filtrate density is consistent across the duplicate measurements but higher than previous measurements. Slurry density was simply determined by measuring the weight of well-mixed samples in density tubes of measured and traceable volumes (8.506 $\mathrm{mL}$ in both cases here). Both slurry and filtrate densities for HTF-48-12-20/24 are consistently higher than all past densities.

Table 19. Comparison of Densities of Tank 48H Slurry and Filtrate

\begin{tabular}{|c|c|c||}
\hline Sample Number & $\begin{array}{c}\text { Slurry Density, g/mL, } \\
\text { Std Dev }\end{array}$ & $\begin{array}{c}\text { Filtrate Density, g/mL, } \\
\text { Std Dev }\end{array}$ \\
\hline HTF-48-12-20/24 Test A & 1.226 & 1.205 \\
\hline HTF-48-12-20/24 Test B & 1.211 & 1.190 \\
\hline $\begin{array}{c}\text { Average for HTF-48-12- } \\
\text { 20/24 }\end{array}$ & $1.219 \pm 0.011$ & $1.198+/-0.01$ \\
\hline $\begin{array}{c}\text { HTF-E-05-021 } \\
\text { current measurement) }_{\text {HTF-E-05-021 (2005) }}^{3}\end{array}$ & NM & 1.15 (single measurement) \\
\hline HTF-E-04-49,50 (2004) & $1.165 \pm 0.002$ & $1.14+/-0.06$ \\
\hline HTF-E-03-73 (2003) & $1.16 \pm 0.009$ & $1.164+/-0.001$ \\
\hline HTF-E-03-127 (2003) & $1.12 \pm 0.021$ & $1.148+/-0.0056$ \\
\hline
\end{tabular}

\subsubsection{Soluble and Insoluble Solids}

SCO measured the Tank $48 \mathrm{H}$ filtrate density as $1.198 \pm 0.01 \mathrm{~g} / \mathrm{mL}$.

The dissolved solids concentration of the HTF-48-12-20/24 Tank 48H filtrate was $22.08 \pm 0.40$ wt \%. The dissolved solids concentration of the August 24,2004 filtrate was $16.28 \pm 0.27 \mathrm{wt} \%$. The dissolved solids concentration of the June 3, 2003 and September 23, 2003 filtrate was 16.6 wt \%. The 2005 work appears to use the 2004 result.

Insoluble solids concentration was measured a second time after mixing of the carboy was determined to be inadequate for the first sampling. Based on triplicate analysis of the well-mixed carboy, the slurry total solids is $23.23 \pm 0.06 \%$ and the filtrate dissolved solids content is $22.08 \pm$ $0.40 \%$. The second dissolved solids measurement is slightly high when compared with the other two. Table 20 shows the gravimetric results from triplicate samples analysis. The value for the insoluble solids $(1.467 \pm 0.873 \mathrm{wt} \%)$ is calculated using the following formula.

Insoluble Solids $=($ total solids - dissolved solids $) /(1-$ dissolved solids $/ 100)$

Insoluble Solids $=(23.23-22.08) /(1-22.08 / 100)=1.47 \pm 0.873 \mathrm{wt} \%$

Based on this calculation, the insoluble solids measurement is consistent with previous analyses $\left(1.69 \pm 0.22 \mathrm{wt} \%,{ }^{2} 2.18 \pm 0.61 \mathrm{wt} \%,{ }^{1}\right.$ and $\left.2.3 \mathrm{wt} \%{ }^{8}\right)$. The soluble solids content is higher than past work consistent with the current finding that filtrate density is higher than measurements made years ago (see previous section). 
SRNL-STI-2012-00420

Revision 0

Table 20. Comparison of Solids Data with those of Previous Samples

\begin{tabular}{||c|c|c|c||}
\hline Sample Number & wt \% Total Solids & $\begin{array}{c}\text { wt \% Dissolved } \\
\text { Solids }\end{array}$ & $\begin{array}{c}\text { wt \% Insoluble } \\
\text { Solids }\end{array}$ \\
\hline HTF-48-12-20/24 Test A & 23.16 & 21.87 & 1.651 \\
\hline HTF-48-12-20/24 Test B & 23.24 & 22.55 & 0.891 \\
\hline HTF-48-12-20/24 Test C & 23.28 & 21.83 & 1.855 \\
\hline $\begin{array}{c}\text { Average for HTF-48-12- } \\
\text { 20/24 }\end{array}$ & $23.23 \pm 0.06$ & $22.08 \pm 0.40$ & $1.467 \pm 0.873 *$ \\
\hline & & & \\
\hline HTF-E-05-021 (2005) & $20.19 \pm 0.08$ & $17.68 \pm 0.14$ & $3.05 \pm 0.15$ \\
\hline HTF-E-04-49,50 (2004) & $19.08 \pm 0.08$ & $17.68 \pm 0.14$ & $1.69 \pm 0.22$ \\
\hline HTF-E-03-127 (2003) & $18.42 \pm 0.205$ & $16.60 \pm 0.402$ & $2.18 \pm 0.607$ \\
\hline HTF-E-03-73 (2003) & $17.77 \pm 0.117$ & $16.55 \pm 0.123$ & $1.46 \pm 0.24$ \\
\hline
\end{tabular}

* Insoluble solids for this method is reported with uncertainty at $95 \%$ confidence (2-sigma)

\subsection{Analysis of Data}

An ion balance for the filtrate (Table 21) shows that when the historically high carbonate (by TIC) for the current sample is accounted for, the sum of anion concentration significantly exceeds the cation concentration. This contrasts with the 2005 sample HTF-E-05-021 results where the total cation charge was $3.87 \mathrm{M}$ and total anion charge was $3.14 \mathrm{M}$. Further examination of the current carbonate level may be needed since it is indicated to be significantly higher than historical measurements for Tank $48 \mathrm{H}$. 
Table 21. Tank 48H Filtrate Anion/Cation Balance

\begin{tabular}{|c|c|c|c|}
\hline Analyte & Normal & $\begin{array}{c}1 \sigma \text { Uncertainty, } \\
\text { Normal }\end{array}$ & Method \\
\hline $\mathrm{Al}(\mathrm{OH})_{4}^{-}$ & 0.076 & 0.0057 & ICP-ES \\
\hline $\mathrm{BO}_{3}{ }^{3-}$ & 0.128 & 0.0305 & ICP-ES \\
\hline $\mathrm{C}_{2} \mathrm{O}_{4}{ }^{2-}$ & 0.024 & 0.0211 & IC \\
\hline $\mathrm{Cl}^{-}$ & 0.0053 & 0.0004 & IC \\
\hline $\mathrm{CO}_{3}{ }^{2-}$ & 2.77 & 0.058 & TIC/TOC \\
\hline $\mathrm{NO}_{2}^{-}$ & 0.535 & 0.016 & IC \\
\hline $\mathrm{NO}_{3}^{-}$ & 0.180 & 0.0232 & IC \\
\hline $\mathrm{OH}^{-}$ & 1.02 & 0.02 & Titration \\
\hline $\mathrm{PO}_{4}{ }^{3-}$ & 0.0044 & 0.001 & IC \\
\hline $\mathrm{SO}_{4}{ }^{2-}$ & 0.0043 & 0.0064 & IC \\
\hline Total Anion Charge & 4.77 & & Calculation \\
\hline $\mathrm{K}+$ & 0.007 & 0.00058 & ICP-ES \\
\hline $\mathrm{Na}+$ & 3.73 & 0.334 & ICP-ES \\
\hline Total Cation Charge & 3.74 & 0.334 & Calculation \\
\hline
\end{tabular}




\subsection{References}

${ }^{1}$ D. P. Lambert, T. B. Peters, M. E. Stallings, and S. D. Fink, "Analysis of Tank 48H Samples HTF-E-0373 (June 03, 2003) and HTF-E-03-127 (September 17, 2003)”, WSRC-TR-2003-00720, January 20, 2004.

${ }^{2}$ D. P. Lambert, T. B. Peters, M. J. Barnes, and S. D. Fink, "Analysis of Tank 48H Samples HTF-E-04-49 and HTF-E-04-50 (August 23, 2004)", WSRC-TR-2004-00514, November, 2004.

${ }^{3}$ F. F. Fondeur, D. P. Lambert, and S. D. Fink, “Analysis of Tank 48H Sample HTF-E-05-021”, WSRCTR-2005-00358, October 3, 2005.

${ }^{4}$ K. Subramanian, TTR "Technical Task Request - Sampling and Characterization of Tank 48H Waste", G-TTR-H-00004, Rev. 0, October 20, 2011.

${ }^{5}$ T. B. Peters, C. A. Nash, F. F. Fondeur, K. M. Taylor-Pashow, T. L. White, D. J. Newell, and S. D. Fink, TTQAP "Task Technical and Quality Assurance Plan for Process Optimization for Cu-Catalyzed Peroxide Oxidation of Tank 48H Tetraphenylborate”, SRNL-RP-2011-01525, Rev. 1, March 2012.

${ }^{6}$ K. Subramanian, TTR "Technical Task Request - Process Optimization for Copper-Catalyzed Peroxide Oxidation of Tank 48H Bulk Tetraphenylborate", G-TTR-H-00005, Rev. 1, February 14, 2012.

${ }^{7}$ F/H Area Laboratory Services, Sample ID 200596113, results transmitted from Janice Cook to SRNL on $7 / 31 / 2012$.

${ }^{8}$ D. D. Walker, W. T. Boyce, C. J. Coleman, D. P. DiPrete, T. B. Edwards, A. A. Ekechuckwu, C. W. Hsu, S. F. Peterson, L. L. Tovo, and M. J. Whitaker, "Tank 48H Waste Composition and Results of Investigations of Analytical Methods", WSRC-TR-97-0063, April 2, 1997. 


\section{Distribution:}

S. D. Fink, 773-A

K. M. Fox, 999-W

B. J. Giddings, 786-5A

C. C. Herman, 999-W

S. L. Marra, 773-A

F. M. Pennebaker, 773-42A

E. A. Brass, 249-8H

S. P. Simner, 249-8H

P. R. Jackson, 703-46A

K. H. Subramanian, 249-8H

C. I. Aponte, 249-8H

T. B. Peters, 773-42A

C. A. Nash, 773-42A

C. J. Martino, 773-42A

J. M. Pareizs, 773-A 